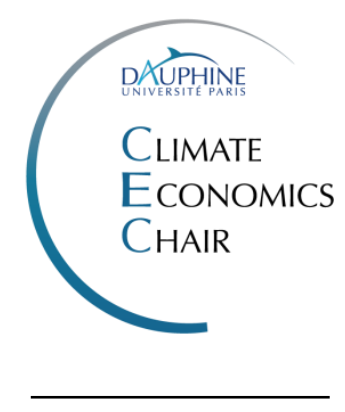

KEYWORDS

Co-firing

Biomass

Renewable electricity obligation

Electricity mix

$\mathrm{CO}_{2}$ emissions

Social cost of carbon
Chaire Economie du Climat

Palais Brongniart, 4ième étage

28 place de la bourse
WORKING PAPER

$n^{\circ} 2017-04 \cdot$ May 2017

\section{CO-FIRING COAL WITH BIOMASS} UNDER MANDATORY OBLIGATION FOR RENEWABLE ELECTRICITY:

\author{
IMPLICATION FOR THE ELECTRICITY MIX
}

\author{
Vincent BERTRAND 1,2
}

This paper analyses the effect of recognizing co-firing coal with biomass as a renewable energy sources (RES) so as to meet the mandatory obligations in electricity. We provide simulations for the French and German electricity mix, with investigations about consequences for cost savings in the power sector and $\mathrm{CO}_{2}$ emissions. Results indicate that, if co-firing is recognized as a RES, coal would crowd-out traditional RES, not only with increased generation from existing coal plants, but also with additional investments in coal that would be substituted for traditional RES. Investments in coal may be more significant in France than in Germany, which may correspond to adding up to $243 \%$ of coal capacity in French electricity by 2030, whereas the same progression is $27 \%$ in Germany. Regarding $\mathrm{CO}_{2}$ emissions, we find sharp increases when co-firing is recognized as a RES. The rise is more significant in Germany due to more coal capacities. In the case of France, the magnitude of increased emissions highly depends on the share of nuclear electricity, with fewer increase when old nuclear stations are prolonged. Finally, we find that including co-firing in the set of RES reduces the overall costs associated with managing the power system. We also balanced the cost saving for the power sector with the increased social cost from higher $\mathrm{CO}_{2}$ emissions. Results show that the cost saving is dominated by the increased carbon cost for the society if the carbon valuation is around 100 Euros per $\mathrm{tCO}_{2}$, except in France when old nuclear stations are prolonged.
1. CRESE EA3190, Univ. Bourgogne Franche-Comté, F-25000 Besançon, France 2. Climate Economics Chair, Univ. Paris Dauphine, Paris, France 


\section{Introduction}

In the last few years, co-firing coal with biomass has become very popular in the European power sector, where firms have to comply with stringent policies to reduce $\mathrm{CO}_{2}$ emissions and increase renewable electricity. Co-firing provides short-term opportunities for increasing the share of renewable energy sources (RES) and reducing $\mathrm{CO}_{2}$ emissions in a very cost effective way, through conventional technologies that are not subject to problems of intermittency and that do not require additional investments.

In addition to exemption from surrendering $\mathrm{CO}_{2}$ allowances under the European Union Emission Trading Scheme (EU ETS) when burning biomass (equivalent to a zero emission factor), several European states have implemented arrangements to include co-firing in their support schemes for renewable electricity. This include countries with high coal electricity such as Poland or the UK, which raised concerns about consequences for coal contribution in electricity mix (even through co-firing with biomass) and resulting $\mathrm{CO}_{2}$ emissions. As recently pointed out in debates on energy agreements at the Dutch parliament, it may seem strange that, on the one hand, some coal plants are set to close down (notably due to European limits about $\mathrm{SO}_{\mathrm{X}}$ and $\mathrm{NO}_{\mathrm{X}}$ emissions), and, on the other hand, the same units can get subsidies when co-firing biomass. Beyond, this raises questions about the actual incentives to invest in traditional RES technologies (e.g. wind, solar, dedicated biomass units) to meet European targets, and the consequences for the future energy mixes.

The aim of this paper is to analyze consequences for electricity mix when co-firing is recognized as renewable electricity. To do this, we use the Green Electricity Simulate (GES), which is a simulation model for electricity, which is designed to focus on biomass-based electricity and co-firing in European countries (Bertrand and Le Cadre, 2015). We run simulations including, either or not, co-firing in the set of RES technologies that are accounted for to meet the RES targets. We focus on France and Germany, rather than considering countries that have already included provisions to support co-firing as another RES. France and Germany offer good cases of study for our analysis, because of their important coal capacities (the French capacity is not negligible in volume, although far less significant than the German, see Table 3), and given that no support scheme for co-firing has been implemented in these countries so far. 
Results confirm that recognizing co-firing as a RES would jeopardize investments in traditional RES, which would be largely ousted in favor of an increased generation from existing coal power stations under co-firing, and some new investment in coal. The additional coal investments are more substantial in France because the French coal capacities are smaller than the Germans, which limits the ability to use existing coal plants in order to meet the RES targets through co-firing. The additional French coal capacities may attain up to $18 \mathrm{GW}$ when the model is implemented with exogenous decommissioning of old nuclear power plants. Comparatively, the maximal additional coal capacity in Germany is close to $14 \mathrm{GW}$ when cofiring is in the set of RES, which corresponds to a progression of about $27 \%$ for coal in 2030 compared with initial capacity, whereas the same progression is more than $243 \%$ in France when old nuclear stations are decommissioned (107\% when nuclear is prolonged), with almost $26 \mathrm{GW}$ of coal accounting for $20 \%$ of the 2030 French capacity mix. Hence, including co-firing in RES may more deeply modify the French capacity mix, in which coal may change status and become an important source of French electricity.

Regarding $\mathrm{CO}_{2}$ emissions, results indicate that recognizing co-firing as a RES generates sharp increases because of reduced traditional RES (carbon-free) and more coal in electricity. This effect is more significant in Germany than in France due to much more coal capacities. Moreover, in the case of France, the magnitude of carbon increase highly depends on the share of nuclear, with fewer increase when old nuclear stations are prolonged. Finally, we show that including co-firing in the set of RES reduces the overall costs associated with managing the power system, because this allows complying with the RES constraint through a conventional and low-cost option that does not require additional investments in most cases. When balancing this cost saving with the increased social cost from higher $\mathrm{CO}_{2}$ emissions, results show the cost saving may be dominated by the increased carbon cost with a high carbon valuation around 100 Euros per $\mathrm{tCO}_{2}$. An exception comes from France when old nuclear stations are prolonged. In this case, the cost saving is very high and the increased $\mathrm{CO}_{2}$ emissions are slight (because massive cheap and carbon-free nuclear remains in base-load generation), so that the cost saving always dominates the increased carbon cost.

The remainder of the paper is organized as follows. Section 2 gives an overview of existing support schemes for renewable electricity in European countries that include provisions for co-firing. In section 3, we provide a brief presentation of the methodology and data. Section 3 presents results and discussions. Section 4 concludes. 


\section{Co-firing in the renewables electricity support schemes of European countries: An overview}

The option to co-fire biomass with coal has been implemented in numerous European coal power stations. Major co-firing applications include large coal plants such as Ferrybridge (2000 MW, UK), Fiddler's Ferry (2000 MW, UK), Amer (1000 MW, Netherlands), Gelderland (630 MW, Netherlands), Ensted (620 MW, Denmark), Lagisza (460 MW, Poland), etc. ${ }^{1}$

The treatment of co-firing in support schemes for renewable electricity is highly heterogeneous among European countries. In general, in most cases, co-firing is not accounted for as a RES, and, as such, it is not awarded with subsidies. However, there are notable exceptions to this, with significant countries of high coal electricity that have included provision for co-firing in their support schemes. Table 1 provides an overview of treatments for coal plants under co-firing in support schemes from different European countries.

Table 1: Treatment for co-firing in support schemes of European countries (Bubholz and Nowakowski, 2010).

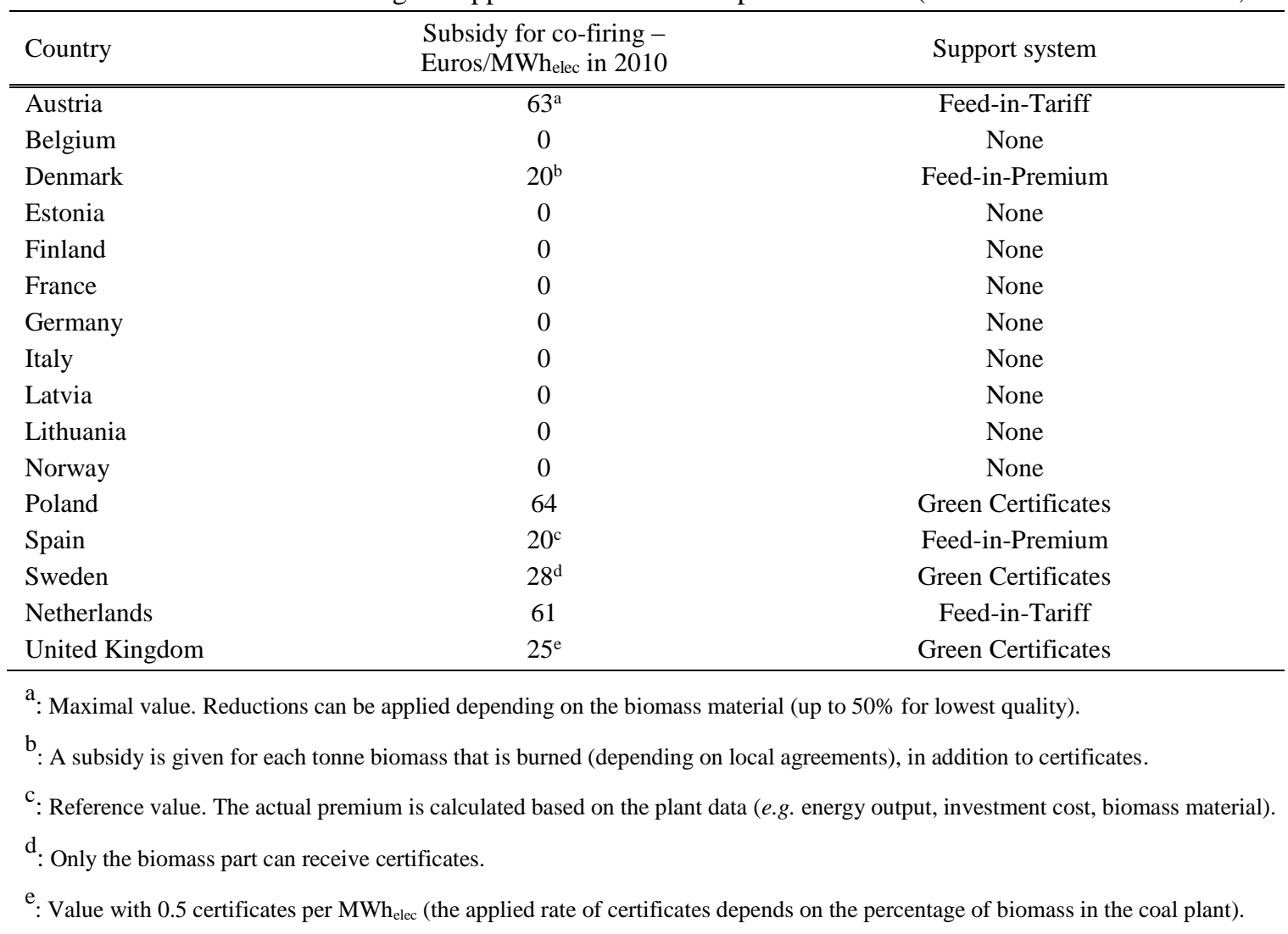

\footnotetext{
${ }^{1}$ The Drax power station (UK) is known as the world biggest biomass-based power station with 1220 MW of $100 \%$ biomass generation capacity, i.e. two of the six Drax units (conversion of a third unit has been recently decided, which will increase the biomass capacity to $1880 \mathrm{MW}$ ). Such a conversion project would not be considered as co-firing because it only burns biomass, and, in the UK, it is entitled to receive a more generous subsidy treatment compared with co-firing (Table 2).
} 
In the UK, a banding has been introduced, which awards different co-firing configurations with varying rates of certificates. Whereas 1.5 Renewables Obligation Certificates (ROCs) are given for each MWh of electricity generated in dedicated biomass units, the ROC rate (ROC per $\mathrm{MWh}_{\mathrm{elec}}$ ) is lower than one when co-firing is involved. The rate ranges from 0.3 to 0.9 , depending on the percentage of biomass under co-firing (Table 2).

Table 2: Cost of generating electricity with biomass in the UK under ROC banding (Argus, 2016; Alexander et al., 2013).

\begin{tabular}{lccc}
\hline & ROC rate & $\begin{array}{c}\text { ROC value } \\
(\text { Euros/MWhelec })^{\mathrm{a}}\end{array}$ & $\begin{array}{c}\text { Electricity Cost } \\
\left(\text { Euros/MWhelec }^{\mathrm{b}}\right.\end{array}$ \\
\hline \hline Dedicated biomass & 1.5 & 78.60 & 117.41 \\
Conversion - 100\% biomass & 1 & 52.40 & 91.21 \\
Co-firing - More than 85\% biomass & 0.9 & 47.16 & 85.97 \\
Co-firing - 50 to 85\% biomass & 0.6 & 31.44 & 70.25 \\
Co-firing - Up to 50\% biomass & 0.3 & 15.72 & 54.53 \\
\hline
\end{tabular}

a: Based on the ROC value of May 2016 (52.40 Euros).

b. Cost associated with 34\% efficiency power stations, and market prices (coal, EUA, wood pellets) of May 2016

The UK system used to be more generous regarding co-firing, with one ROC per $\mathrm{MWh}_{\text {elec }}$ of co-fired electricity, regardless of the configuration. In order to avoid too heavy development of co-firing in the country, a banding has been introduced so as to limit the level of subsidy. Nevertheless, even with the banding system, co-firing biomass with coal tends to be still more cost efficient, compared with investments in new dedicated biomass units.

In the Netherlands, which is another country with high co-firing, the SDE+ (Stimulering Duurzame Energie) auction subsidy-system for renewables, provides producers of co-fired electricity with grants, as other RES. The SDE+ has been introduced in 2015, and, basically, the (sealed-bid) auction gives bonus payment to compensate for the difference between the market prices for electricity (which are based on fossil sources) and the electricity cost from RES. $^{2}$ The schemes works with multiple bidding phases (nine in 2015, and four in 2016), with a budget cap and a maximal premium for each technology and phase. Each bidder submits a (bid) premium (lower than the maximal) and a production. For each technology, the auction continues until the budget is reached. Bidders with the lowest bids are awarded first, and they receive the premium they bid. In the co-firing category, producers can bid for a maximum

\footnotetext{
${ }^{2}$ For the readers familiar with earlier application of emission trading in the UK (the so-called UK ETS), the design is pretty similar, with participants bidding for premiums that cover increased cost associated with efforts (increased RES generation with the SDE+, and carbon abatements in the case of the UK ETS).
} 
premium of 107 Euros/MWhelec for a period of eight years (Netherlands Enterprise Agency, 2016; AURES-Ecofys, 2016).

During the 2016 auctions, co-firing units were among the biggest winners. For example, in the first phase of July, several coal stations received around 1.5 billion Euros to co-fire up to 50 percent biomass, for a total SDE+ budget of 8 billion Euros in 2016. However, whether these subsidies for co-firing will be actually implemented or not remains uncertain, because of the Dutch government plans to close all coal stations by 2020 , which is still under debate. ${ }^{3}$

In the context of our paper, we choose to focus on France and Germany, rather than directly considering those countries with RES supports given to co-firing. These two countries offer good cases of study for our analysis, because they have substantial coal capacities and no subsidy for co-firing, so as they give relevant counterfactuals to investigate consequences of implementing such provision for co-firing in RES support schemes.

Table 3: Coal in the 2010 European electricity (Eurelectric, 2011).

\begin{tabular}{|c|c|c|c|c|c|c|c|c|}
\hline & Germany & Poland & UK & Denmark & France & Netherlands & Greece & Belgium \\
\hline Coal power capacitya & $\begin{array}{l}55547 \\
(29 \%)\end{array}$ & $\begin{array}{l}34305 \\
(86 \%)\end{array}$ & $\begin{array}{l}28068 \\
(28 \%)\end{array}$ & $\begin{array}{c}9272 \\
(42 \%)\end{array}$ & $\begin{array}{l}8153 \\
(6 \%)\end{array}$ & $\begin{array}{l}5641 \\
(14 \%)\end{array}$ & $\begin{array}{l}4744 \\
(29 \%)\end{array}$ & $\begin{array}{l}1156 \\
(6 \%)\end{array}$ \\
\hline Coal power generation & $\begin{array}{l}262.4 \\
(38 \%)\end{array}$ & $\begin{array}{c}154 \\
(87 \%)\end{array}$ & $\begin{array}{l}102.9 \\
(26 \%)\end{array}$ & $\begin{array}{c}27 \\
(42 \%)\end{array}$ & $\begin{array}{l}19.8 \\
(4 \%)\end{array}$ & $\begin{array}{c}27.1 \\
(15 \%)\end{array}$ & $\begin{array}{c}27.5 \\
(49 \%)\end{array}$ & $\begin{array}{c}6.2 \\
(6 \%)\end{array}$ \\
\hline
\end{tabular}

a: Countries are ranked from left to right by increasing coal capacities.

Evidently, Germany is by far a much greater country than France regarding the share of coal in the electricity. However, even though coal represents a pretty small share of French electricity, the associated volumes are quite significant compared with other European country, in which coal is well-known as an important source of electricity (Table 3)

\section{Simulation methodology}

\subsection{Model description}

GES is a dynamic simulation model that is designed to investigate questions related to biomass-based electricity in the European countries, with a special focus on the biomass cofiring in coal plants. The model minimize the overall cost of electricity (generation and

\footnotetext{
${ }^{3}$ www.argusmedia.com
} 
investment), over the 2010-2030 time interval, with a range of economic, technical or legal constraints: capacity (generation $\leq$ available capacity), market clearing for electricity, share of RES in power generation, physical constraints associated with co-firing (loss on efficiency of coal plants and percentage of biomass that can be co-fired depending on the resource quality), etc. In this work, with use the French and the German modules form the 1.0 version (Bertrand and Le Cadre, 2015).

For each year in the considered time interval, the model determines the power generation mix, based on a merit order logic, and investment decisions, so as to meet electricity demand at the least cost. It computes the optimal dispatch of generation capacities into intra-annual hourly time slices with unequal power demand. This reflects different load levels associated with more or less electricity demand.

The modeling framework also allows investigating consequences of modifications in the electricity park, through investments in new power stations and decisions regarding decommissioning or prolongation of old units whose the age is strictly higher than the theoretical lifetime. ${ }^{4}$ Hence, the structure of the fleet is made flexible, which allows analyzing any change in the electricity mix in favor of biomass with a degree of flexibility that depends on relative prices, technological and legal aspects. Figure 1 provides an overview of the model framework.

\footnotetext{
${ }^{4}$ At the beginning of each year, the model identifies which are the out-of-lifetime power plants (i.e. age > theoretical lifetime). Once the set of out-of-lifetime power plants have been identified, the model implements calculation for each unit in this set, which allows estimating if it is a profitable option to refurbish and prolong those units, or if it is cheaper to decommission it and consider new investments. The calculation relies on comparing the Levelized Lifetime Costs of Electricity (LLCOE) associated with new or prolonged units (Bertrand and Le Cadre, 2015). In the case of coal plants, this calculation can be implemented taking into account the ability to co-fire coal with biomass or not.
} 


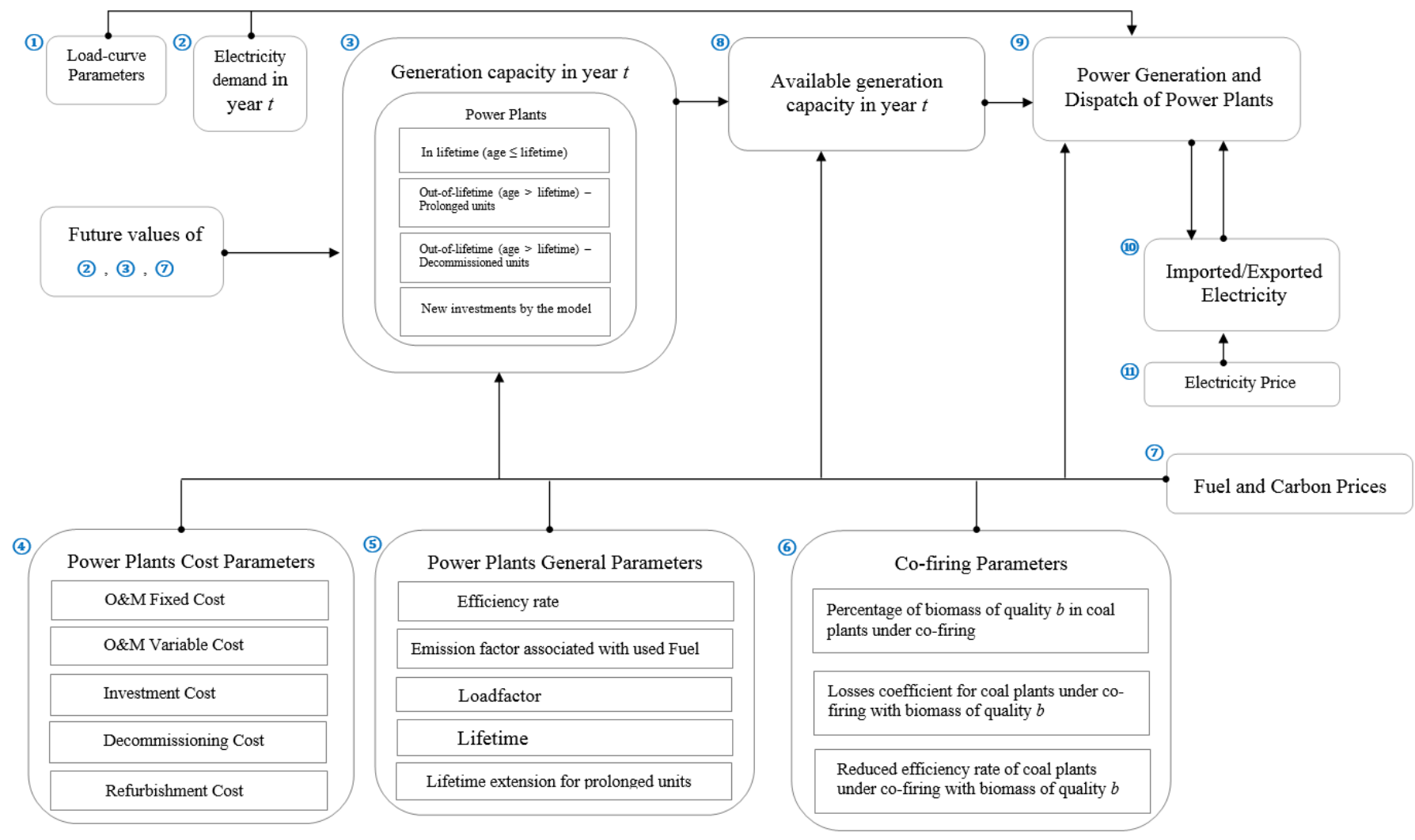

Figure 1: Overview of the GES optimization problem.

\subsection{Data and model calibration}

The dataset for the power system is based on a literature review that provides representative values for cost and technical parameters associated with different power technologies of varying vintages: efficiency rates of power plants, load-factors, fixed and variable operation and maintenance costs, refurbishment costs, decommissioning costs, theoretical lifetimes (depending on whether stations have been prolonged or not), etc. ${ }^{5}$

In order to derive realistic projections, the model has been calibrated to actual market data. We focused on reproducing the observed yearly generation by fuel, through iterative adjustments of availability and marginal costs, so as to best replicate the French and German power generation mix as given by (RTE, 2011) and Eurelectric (2011). Such model calibration is a standard exercise in simulation. This constitutes a necessary second-best approach to avoid too much departure of simulation results compared with actual data. In particular, as pointed out in previous studies, simulations relying on unadjusted models are likely to generate errors in estimations derived from uncorrected power generation. For

\footnotetext{
${ }^{5}$ All the data and references are available in online appendices from Bertrand and Le Cadre (2015).
} 
instance, estimating $\mathrm{CO}_{2}$ emissions based on (simulated) uncorrected power generation can lead to significant bias in abatements estimates due to divergences in utilization of power technologies with varying carbon intensity compared with real world responses under similar conditions (Delarue et al., 2010; Weigt et al., 2013; Solier, 2014).

Coal (bituminous), gas, oil and carbon prices are based on the Current Policy Scenario (CPS) from International Energy Agency (IEA), and other fuel prices are derived from literature review. In all cases, the model considers price trends that are indexed on the Average Annual Growth Rates (AAGR) from the IEA-CPS scenario, as well as other projections (from different references) reflecting specific evolutions in other fuel industries (uranium, lignite, solid biomass, biogas, bio-liquids, and mixed grade waste). ${ }^{6}$

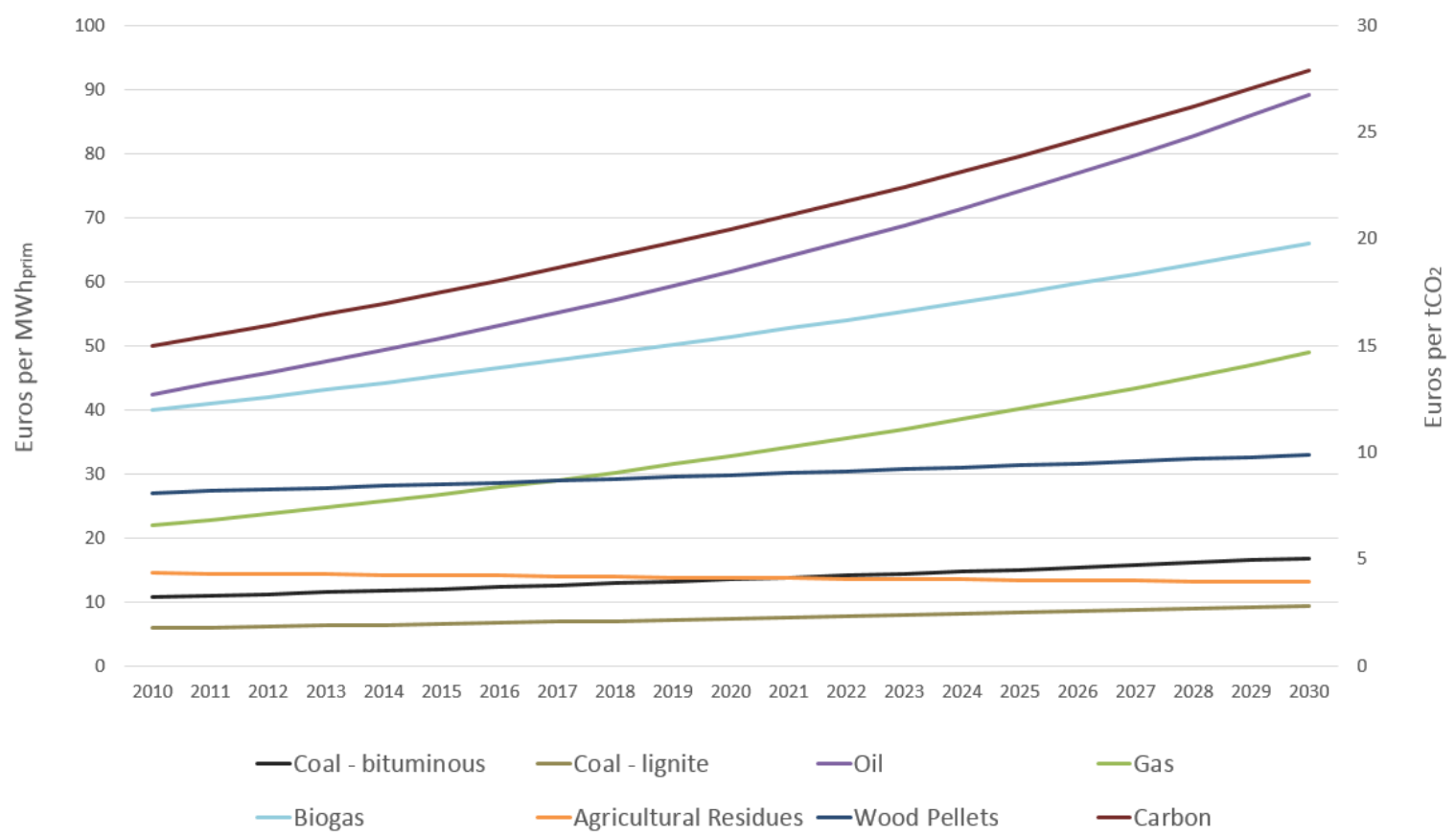

Figure 2: Main fuel and carbon prices.

The annual electricity demands is obtained from the 2010 ENTSO-E values to which we apply the AAGR from the IEA-CPS scenario to compute projections over the time interval. ${ }^{7}$ The resulting yearly demands are then disaggregated on hourly levels, using weighting coefficient reflecting intra-annual time slices with varying length and power load (Bertrand and Le Cadre, 2015).

\footnotetext{
${ }^{6}$ All the price data is available in Bertrand and Le Cadre (2005), with detailed calculations in online appendices.

${ }^{7}$ See Power Statistics on www.entsoe.eu.
} 
Regarding the installed capacities for power plants, the models uses data from the World Electric Power Plants (WEPP) data base by Platts, which provides a global inventory of electric power stations with information such as location, year of commissioning, size, etc. In the case of Germany, the data has been completed with a listing of planned nuclear decommissioning to account for the 2011 decision from the German government to close all the country's nuclear power plants by 2022 (Appendix A). This allows implementing exogenous reduction of nuclear capacity in the data for the model, in line with the German nuclear phase-out plan. In the case of France, in order to investigate the effect of reductions in the French nuclear capacities (similar to the German phasing-out and in line with the French nuclear strategy enacted by the France's energy transition law of July 2015), we have included an additional constraint in the model that proscribes prolongation of out-of-lifetime nuclear stations (that would be prolonged by the model otherwise). This is equivalent to an exogenous decommissioning of old nuclear power plants. ${ }^{8}$

\subsection{RES obligations and co-firing}

In order to investigate the question of how co-firing may impact the electricity mix if it is recognized as a RES, we run simulations by including, either or not, co-firing in the set of RES technologies that are accounted for to meet the RES targets. As a simplification, we assume that only the biomass part from the primary energy in coal plants is accounted for as a RES. Hence, we run the model by considering either equation (1a) or (2a), depending on whether co-firing is included or not in the set of RES:

$\sum_{u \in U R E S} P_{t, u}^{i} \geq \tau_{2020}^{i} \times\left(\sum_{u \in U} P_{t, u}^{i}\right)$

$\sum_{u \in U R E S} P_{t, u}^{i}+\sum_{u \in U C} \sum_{b \in F S B}\left(\eta_{u, b}^{c f} F_{t, u, b}^{i}\right) \geq \tau_{2020}^{i} \times\left(\sum_{u \in U} P_{t, u}^{i}\right)$

where $P_{t, u}^{i}$ stands for power generation from unit $u$ in country $i \in$ [France, Germany] during year $t, \forall t \in[2020, \ldots, 2030] . \tau_{2020}^{i}$ is the 2020 RES target of country $i$ (percentage of RES in the overall power generation, see Table 4). $U$ is the set of all power technologies, and FSB represents the set of all solid biomass fuels with varying quality. UC and URES stand for the

\footnotetext{
${ }^{8}$ In general, results from GES indicate that it is always cheaper to prolonged an old nuclear power plants, rather that decommissioning it to consider a new investments. This strongly relies on the IEA calculation assumptions that we used, in which prolongation does not entail additional cost for future decommissioning, because expenses associated with decommissioning have already been provisioned during the theoretical lifetime (i.e. periods in which the age is lower than the theoretical lifetime), whereas new investments need additional provisions for future decommissioning.
} 
sets of coal and RES units, with $U C \subset U$ and $U R E S \subset U$. In (2a), when co-firing is accounted for as a RES, $F_{t, u, b}^{i}$ represents the quantity of solid biomass $b$ that is included in coal plants $u \in U C$ under co-firing. $\eta_{u, b}^{c f}$ is the reduced efficiency rate of coal plants $u \in U C$ under cofiring $(c f)$, due to loss in combustion efficiency with biomass (increased moisture content and presence of air). In this case, $\eta_{u, b}^{c f}<\eta_{u}^{\text {nocf }}$, where $\eta_{u}^{\text {nocf }}$ is the efficiency rate of coal plants under classical configuration, when coal is the only input. ${ }^{9}$

Table 4: 2020 and 2030 RES targets for power generation in France and Germany (BMWi, 2015; CGDD, 2015). The values are expressed in percentage of the 2020/2030 overall power generation.

\begin{tabular}{lll}
\hline \hline France & $\tau_{2020}^{\text {France }}=27 \%$ & $\tau_{2030}^{\text {France }}=40 \%$ \\
Germany & $\tau_{2020}^{\text {Germany }}=35 \%$ & $\tau_{2030}^{\text {Germany }}=50 \%$ \\
\hline
\end{tabular}

In order to consider the 2030 targets, in addition to that of 2020, we add (1) to (1a) or (2b) to (2a):

$$
\begin{aligned}
& \sum_{u \in U R E S} P_{2030, u}^{i} \geq \tau_{2030}^{i} \times\left(\sum_{u \in U} P_{2030, u}^{i}\right) \\
& \sum_{u \in U R E S} P_{2030, u}^{i}+\sum_{u \in U C} \sum_{b \in F S B}\left(\eta_{u, b}^{c f} F_{2030, u, b}^{i}\right) \geq \tau_{2030}^{i} \times\left(\sum_{u \in U} P_{2030, u}^{i}\right) .
\end{aligned}
$$

\section{Results and discussions}

\subsection{Implications for electricity mix}

Results confirm that recognizing co-firing as a RES may greatly modify the electricity mix, whatever the country. ${ }^{10} \mathrm{We}$ observe increased contribution of coal when co-firing is accounted for as a RES (co-firing in RES) compared with when it is not (co-firing out RES). Figures 3, 4 and 5 indicate that when co-firing is included in the set of RES technologies, the

\footnotetext{
${ }^{9}$ The model considers different types of solid biomass with varying quality: agricultural residues (AR), wood chips (WC), wood pellets (WP), and torrefied biomass pellets (TOP). Then, the higher the quality is (AR quality $<$ WC quality < WP quality < TOP quality), the higher the percentage of biomass (that can be included in coal plants) is. Moreover, for a given percentage of biomass, the actual reduction in the efficiency rate depends on the type of biomass, based on a loss coefficient that increases when the biomass quality is reduced. Hence, for a given percentage of biomass, $\eta_{u, A R}^{c f}<\eta_{u, W C}^{c f}<\eta_{u, W P}^{c f}<\eta_{u, T O P}^{c f}$ (Bertrand and Le Cadre, 2015).

${ }^{10}$ In order to conserve space, we only report the results associated with implementation of the model with both the 2020 and the 2030 constraints for the RES targets (i.e. (1a) with (1b) or (2a) with (2b)). Alternative settings do not qualitatively modify results. Additional results are available upon request.
} 


\section{RES capacities remain constants so that investments in traditional RES disappear compared}

with the situation in which co-firing is considered as a non-renewable option.
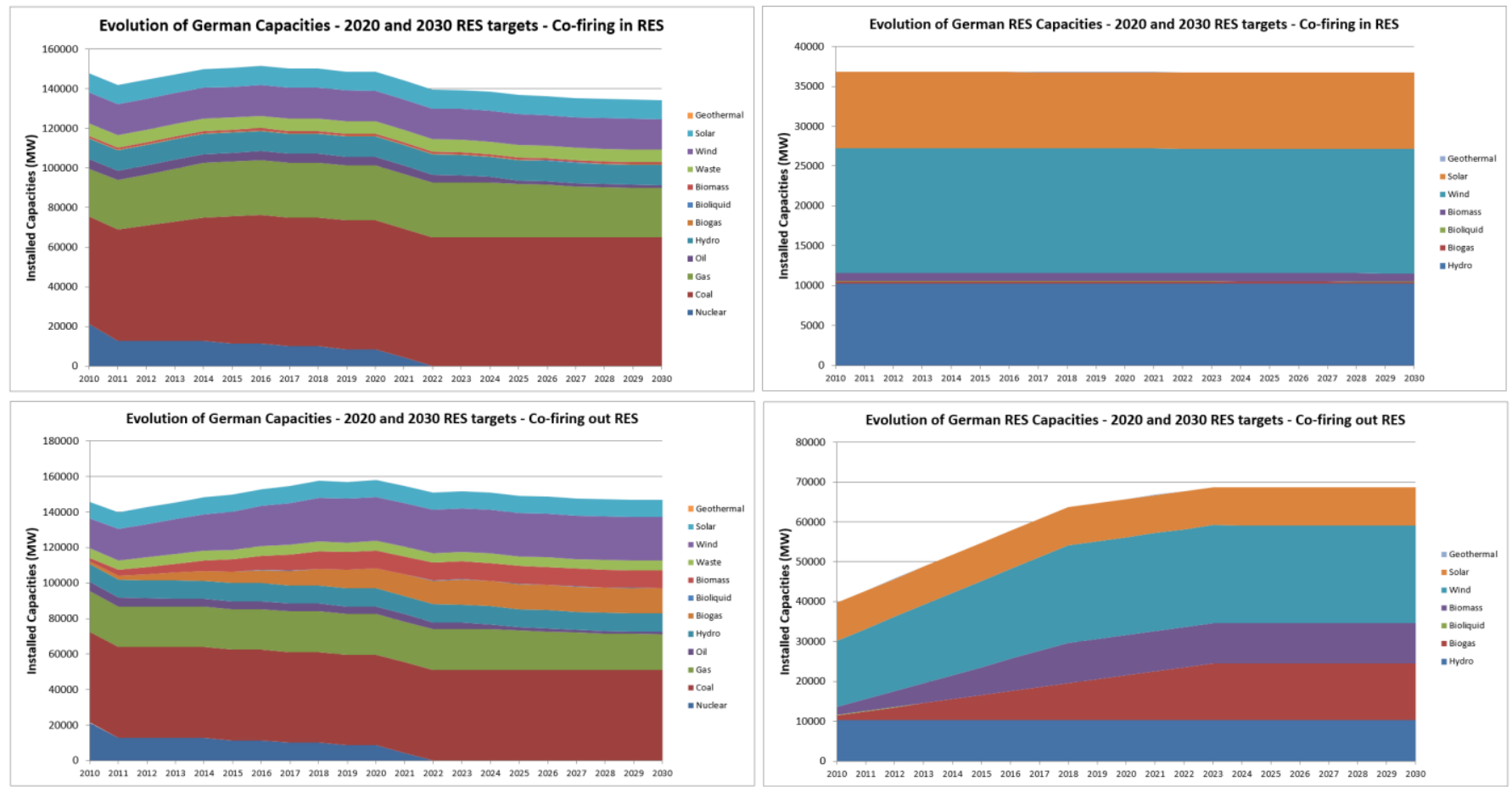

Figure 3: Evolution of the German capacity mix (all technologies, left panel; RES technologies, right panel), depending on whether, or not, co-firing is included in the set of RES technology that are accounted for to meet the RES targets.
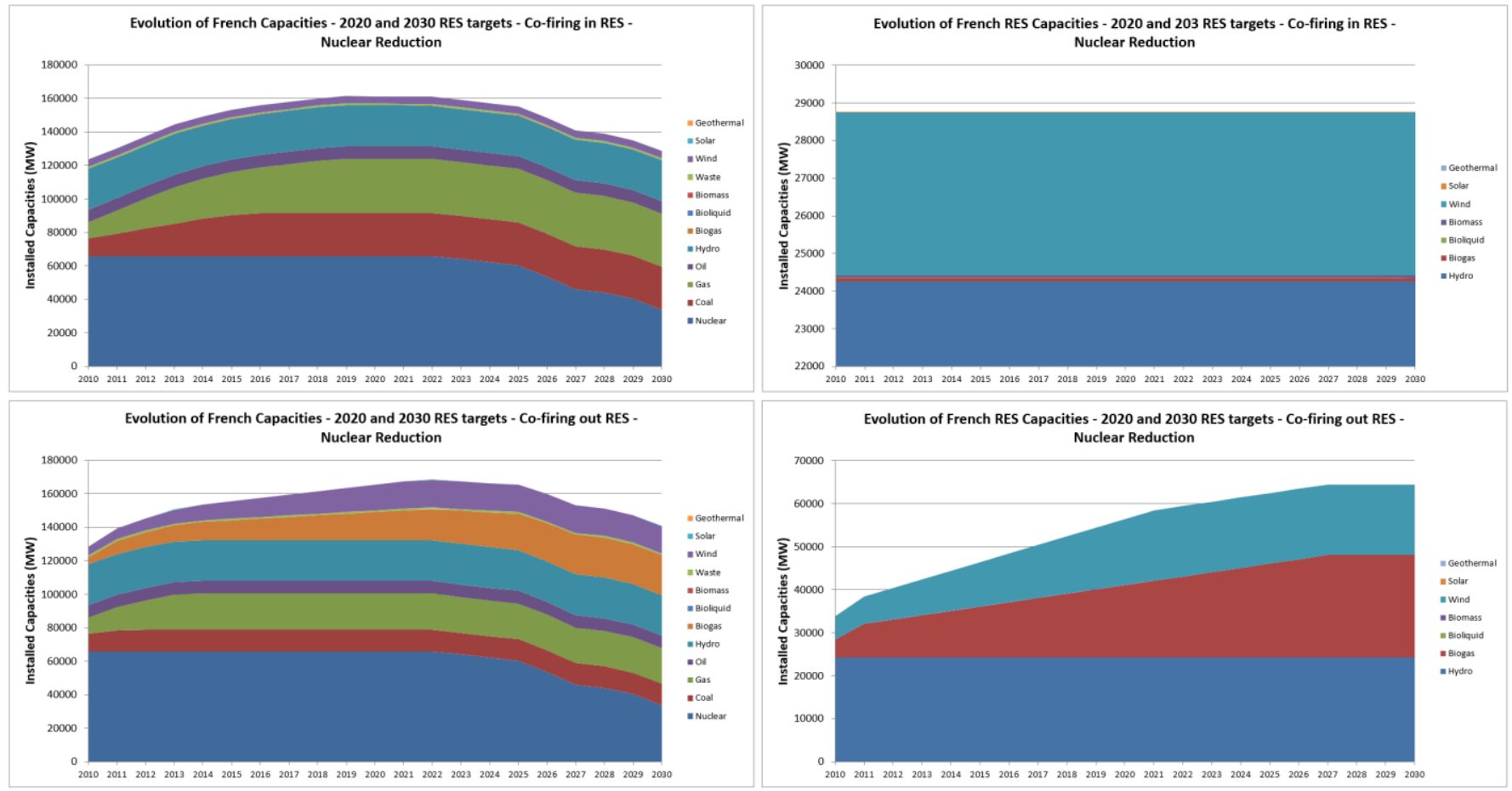

Figure 4: Evolution of the French capacity mix (all technologies, left panel; RES technologies, right panel) with exogenous decommissioning of out-of-lifetime nuclear units, depending on whether, or not, co-firing is included in the set of RES technology that are accounted for to meet the RES targets. 


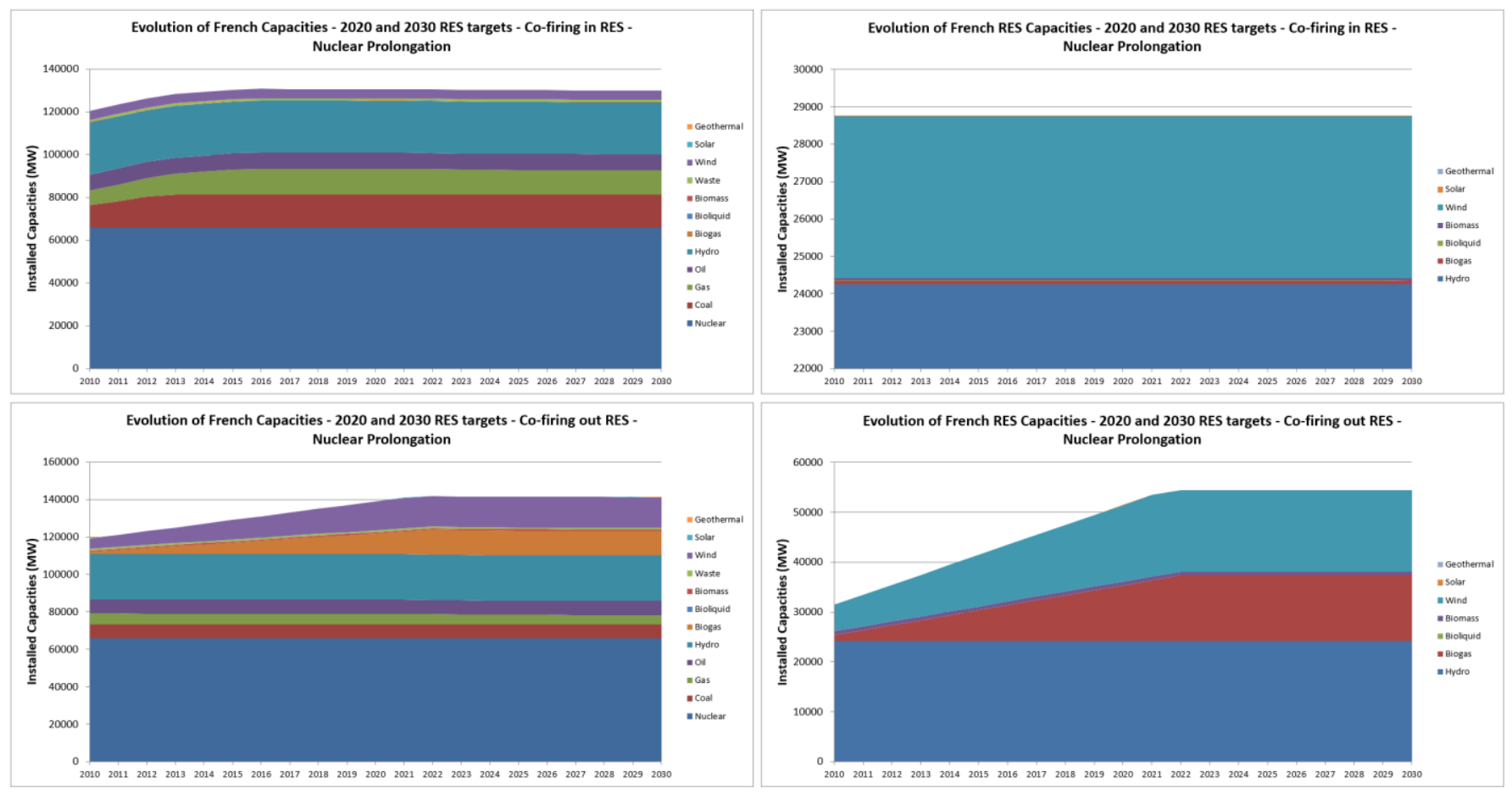

Figure 5: Evolution of the French capacity mix (all technologies, left panel; RES technologies, right panel) with endogenous prolongation of out-of-lifetime nuclear units, depending on whether, or not, co-firing is included in the set of RES technology that are accounted for to meet the RES targets.

The increased coal-based generation is more significant in Germany due to more coal capacity in this country (Figure 6). There are also some new investments in coal when co-firing is in the set of RES (Appendix B). Even though the existing German coal capacity is already very high, it appears that it is not large enough to compensate the reduced investments in traditional RES so as to meet the RES targets through co-firing. The new coal investments vanish when co-firing is excluded from the set of RES. Regarding France, the existing coal capacities are fewer than the Germans (approx. 7.5 GW for the French initial coal capacities against $51.2 \mathrm{GW}$ in Germany), on the one hand, but the RES targets are less significant, on the other hand (Table 4). This translates into two counteracting effects for the need to invest in new coal stations, with French coal capacities that are too small to allowing substantial cofiring so as to meet the RES obligations, but RES targets that are also lower than in Germany (which reduces the need for coal stations to co-fire biomass). The actual effect also depends on the share of nuclear electricity, and the resulting need for conventional capacities, such as coal, to fill the nuclear gap. Overall, when the prolongation of out-of-lifetime nuclear plants is not allowed and co-firing is included in the set of RES, the increased coal contribution is maximal (Figures 6), which translates into more investments in new coal stations (Appendix B). In this case, the additional French coal capacities may attain up to $18 \mathrm{GW}$, whereas these investments disappear when nuclear is prolonged and co-firing is excluded from the set of 
RES. Comparatively, the maximal additional coal capacity in Germany is close to $14 \mathrm{GW}$ when co-firing is in the set of RES. In this case, the 2030 German capacity mix exhibits a progression of about $27 \%$ for coal compared with initial capacity (with $65 \mathrm{GW}$ of coal in 2030 , accounting for $48 \%$ of the capacity mix), whereas the same progression is more than $243 \%$ in France when old nuclear stations are decommissioned, with almost $26 \mathrm{GW}$ of coal accounting for $20 \%$ of the 2030 capacity mix (compared with 5\% when nuclear in prolonged and co-firing is excluded form RES). ${ }^{11}$ That is to say that, if including co-firing in RES would just make the German electricity still more dependent on coal, this may more deeply modify the French capacity mix, in which coal may change status and become an important source of French electricity.

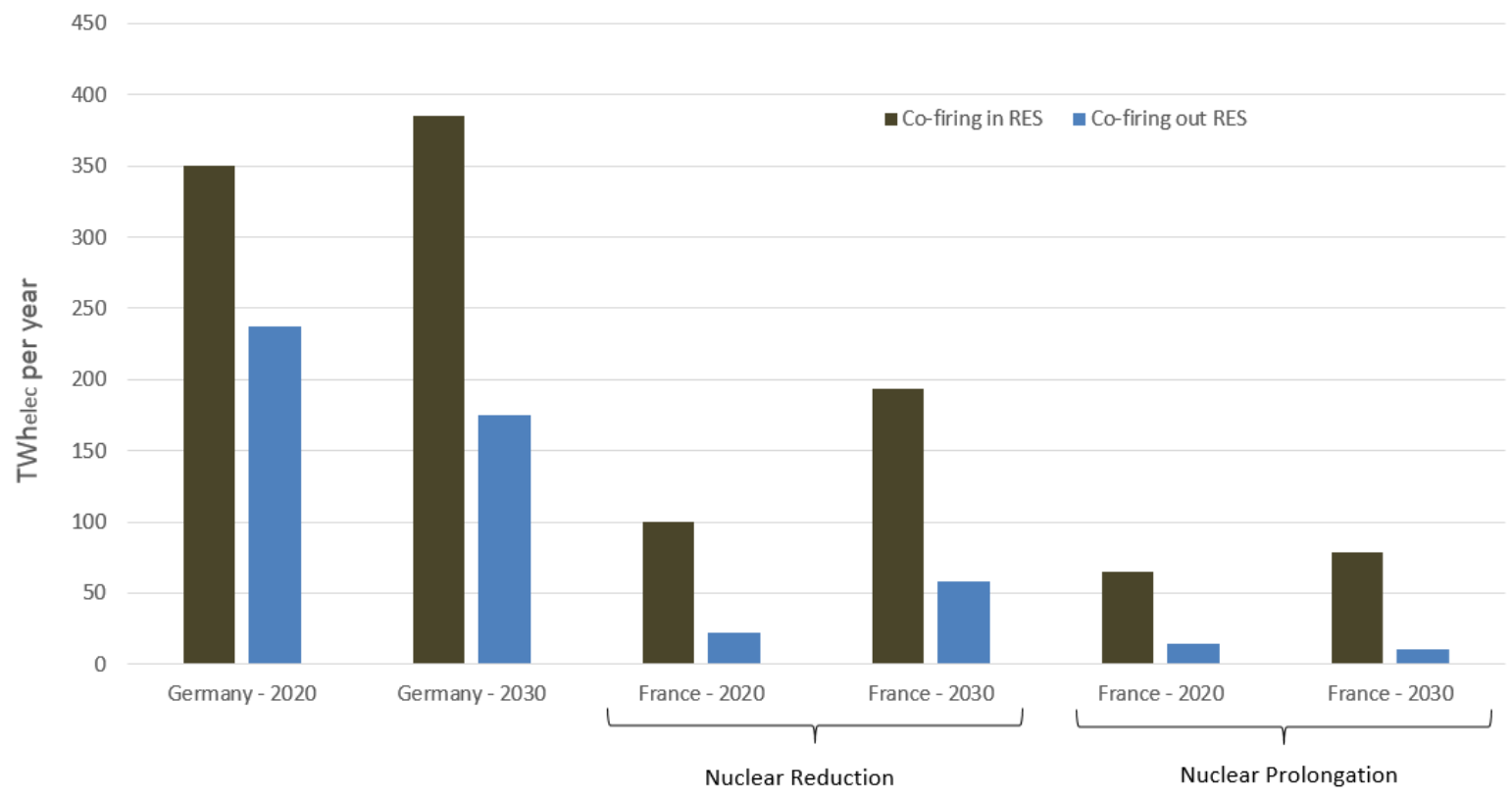

Figure 6: Coal-based power generation (hard-coal and lignite) in France and Germany depending on the treatment co-firing regarding the RES targets.

Figures 3, 4 and 5 show that when co-firing is not included in the set of RES, investments in traditional RES (to meet the mandatory obligations) mainly benefit to biogas, wind and dedicated biomass. First, investments in biogas and dedicated biomass appear as an interesting option, because they are competitive RES technologies that are not subject to the same drawbacks as other RES with problems of intermittency and resulting low availability. In the case of wind, the drawback of low availability is outweighed by a low investment cost

\footnotetext{
${ }^{11}$ When old nuclear stations are prolonged and co-firing is in the set of RES, the French coal capacity increases by $107 \%$ in 2030 compared with initial capacity, with about $15.5 \mathrm{GW}$ of coal accounting for $12 \%$ of the 2030 capacity mix. Here again it is a sharp increase.
} 
with zero marginal cost, so that it remains a competitive option. ${ }^{12}$ Second, investing in biogas and dedicated biomass allows filling the need for new conventional generation capacities with German nuclear phasing-out, exogenous decommissioning of French old nuclear stations, and substantial endogenous decommissioning of out-of-lifetime German combined-cycle units (Figure 10 in Appendix C). ${ }^{13}$ Biogas and dedicated biomass offer interesting characteristics in this context, because they are RES technologies with high availability as conventional units.

In the case of Germany, the fast decrease of conventional capacities with nuclear phasing-out and decommissioning of old combined-cycle units as of 2012, creates an early need for new dispatchable units from the very beginning of the time horizon. This, combined with higher German RES targets, favors more investments in dedicated biomass compared with France. Because the model considers, for each technology, an upper limit for new investments that can be implemented during a year, new capacities have to be more directed towards dedicated biomass in Germany, early in the beginning of the time horizon (dedicated biomass is the second best dispatchable RES after biogas at the beginning of the time horizon, see Figure 11 in Appendix C), once the investments potential for biogas has been exhausted. ${ }^{14}$

\subsection{Implications for $\mathrm{CO}_{2}$ emissions and electricity cost}

All the results above indicate that, if co-firing is included in support schemes for renewable electricity, coal would crowd-out traditional RES, not only with increased generation from existing coal plants, but also with additional investments in coal that would be substituted for wind, dedicated biomass, biogas, and other traditional RES. This may cause political and economic issues in the long-run, with populations that are concerned by tackling climate change effects and reducing the share of polluting fossils in the energy mix.

\footnotetext{
${ }^{12}$ The competitiveness of biogas, wind and dedicated biomass is illustrated by the levelized lifetime cost of electricity (LLCOE) in Appendix C.

${ }^{13}$ It appears that prolonging old combined cycle (gas or oil) is not a profitable option because investing in new fashion units is not very costly (e.g. at least two times cheaper than investing in a comparative new coal station), and it provides a more consequent increase in the efficiency rate compared with competing technologies.

${ }^{14}$ Setting such per technology maximal amounts for yearly investments is a common assumption in simulation models for electricity (e.g. Rentizelas et al., 2012; Kannan and Turton, 2013). This reflects real-world constraints and avoids unrealistic situations in which power generation would rely on a single or very few technologies due to massive investments.
} 


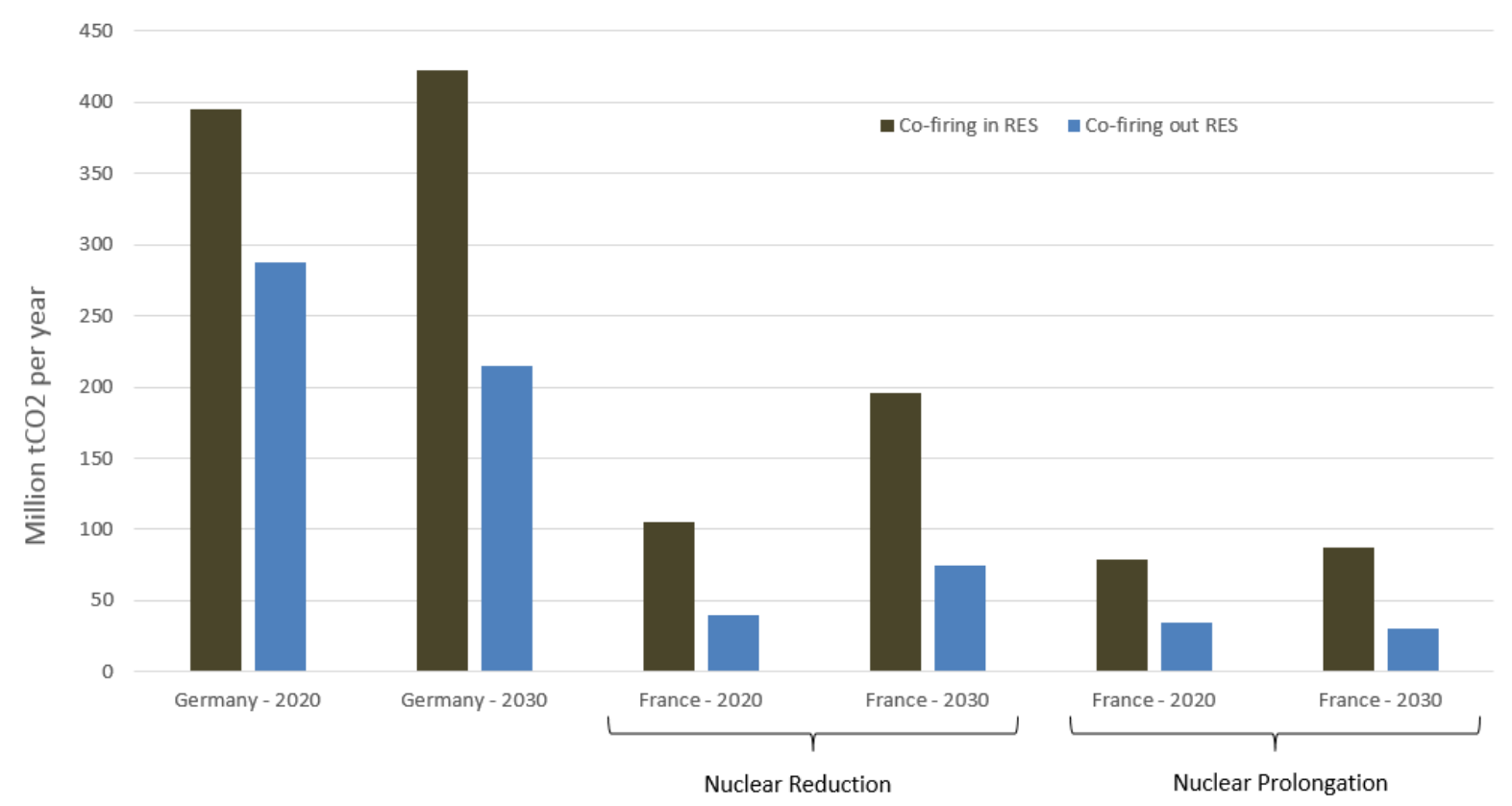

Figure 7: $\mathrm{CO}_{2}$ emissions from power generation in France and Germany depending on the treatment co-firing regarding the RES targets.

Figure 7 shows that recognizing co-firing as a RES generates sharp increases of $\mathrm{CO}_{2}$ emissions due to reduced traditional RES (carbon-free) and more coal in the electricity mix. As illustrated in Figure 6, including co-firing in the set of RES produces a much stronger increase of coal-based generation in the case of Germany, due to much more coal capacities. This translates into a more significant increase of $\mathrm{CO}_{2}$ emissions in Germany compared with France (Figure 7). Although coal plants are mainly used under co-firing in this case, substituting coal with reduced emissions (if implemented with high quality biomass, co-firing allows cutting up to 50 percent of $\mathrm{CO}_{2}$ emissions from exiting coal plants without additional investment) to carbon-free RES, inevitably increases $\mathrm{CO}_{2}$ emissions. Regarding France, the effect on $\mathrm{CO}_{2}$ emissions highly depends on the share of nuclear in electricity. When prolongation of out-of-lifetime nuclear plants is not allowed and co-firing is included in the set of RES, the strong increased contribution of coal (Figures 6), which is substituted to carbon-free RES and nuclear, generate a very significant increase of $\mathrm{CO}_{2}$ emissions (Figure 7).

From a more policy-oriented point of view, the increased $\mathrm{CO}_{2}$ emissions when recognizing co-firing as RES should be balanced with the associated cost saving in the electricity sector, which may allow reducing the cost of policies to attain objectives about renewable electricity. In order to bring the cost savings out, Figure 8 depicts the overall annual costs associated with 
managing the power system (generation, investments, prolongations, provisions, etc) so as to meet electricity demand at the lowest cost. Unsurprisingly, Figure 8 shows that included cofiring in the set of RES reduces the overall electricity cost in all the considered situations, because this allows complying with the RES constraint through a conventional and low-cost option, which does not require additional investments for a large part of involved coal stations that come from the existing capacities. Regarding France, the highest cost reduction associated with recognizing co-firing as RES occurs when the out-of-lifetime nuclear stations are prolonged. In this case, the nuclear plants remain in base-load because they are the cheapest conventional technology. The increased coal generation (under co-firing) is essentially located in higher load levels, where they compete with technologies that are less cost efficient than nuclear. Hence, co-firing allows reducing the cost to comply with the RES constraint without increasing the cost in base-load because nuclear is still dominating this generation segment. ${ }^{15}$ By contrast, when prolongation of nuclear is not allowed, the increased coal generation is mainly substituted to nuclear plants, which entails a substantial cost increase in base-load generation even if the cost to comply with the RES constraint is reduced elsewhere.

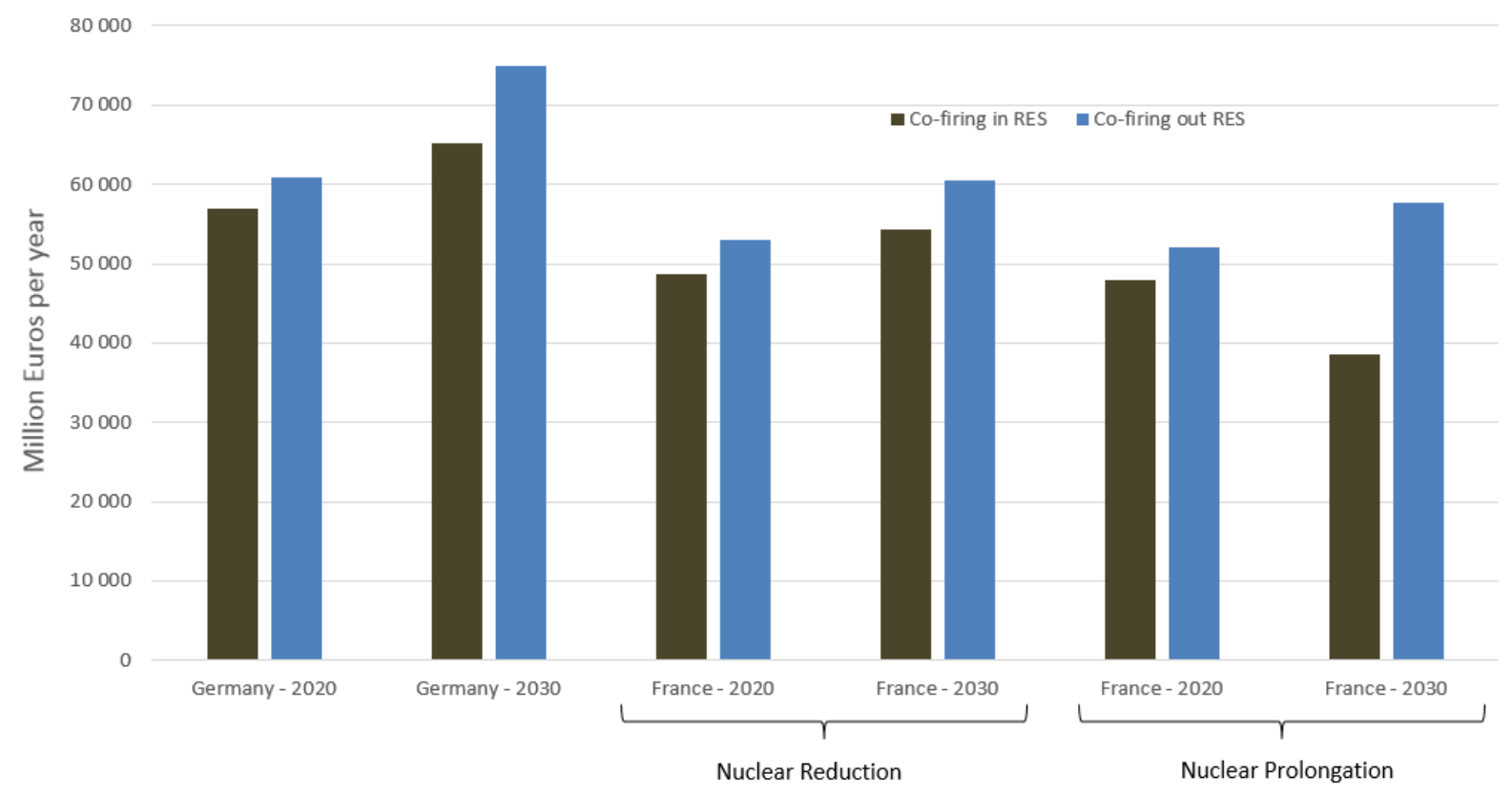

Figure 8: Overall electricity cost to meet annual power demand in France and Germany depending on the treatment co-firing regarding the RES targets.

\footnotetext{
${ }^{15}$ For the same reasons, recognizing co-firing as RES increases more $\mathrm{CO}_{2}$ emissions when nuclear is not prolonged. In this case, coal under co-firing is substituted to nuclear in base-load, which generates more $\mathrm{CO}_{2}$ emission than when nuclear is prolonged and remains in base-load, whereas co-firing is implemented for higher load-level (Figure 7).
} 
A more comprehensive comparison should consider the increased carbon cost for the society, when recognizing co-firing as RES. On the one hand, any cost saving due to including cofiring in the set of RES may allow reducing the cost of policies to attain objectives about renewable electricity. However, on the other hand, if this also entails a rise of $\mathrm{CO}_{2}$ emissions, one should consider the associated increase in the carbon cost so as to evaluate the actual benefit for the society. In order to run this comparisons, we evaluate the increased carbon cost (based on increased emissions that correspond to the difference between values associated with co-firing in and out RES in Figure 7) using a series of valuation for $\mathrm{CO}_{2}$ emissions reflecting different assumptions about the Social Cost of Carbon (SCC). Meanwhile, the carbon cost that is paid by the power sector is still included in the overall electricity cost, and it relies on the price data for $\mathrm{CO}_{2}$ presented in section 3.2.

Nordhaus (2017) provides values for the SCC of 2030 that reflect emission path with current policies, depending on different discount rate. The SCC is in a range of 30 to 165 US Dollars of 2010, which approximately leads to 20 to 130 Euros. ${ }^{16}$ Accordingly, we consider the following valuations to estimate the increased carbon cost for the society: 20, 30, 100 and 130 Euros per $\mathrm{tCO}_{2}$. The computed carbon costs are compared with the overall cost savings in electricity, which corresponds to the difference between values associated with co-firing in and out RES in Figure 8. Results are presented in Figure 9.

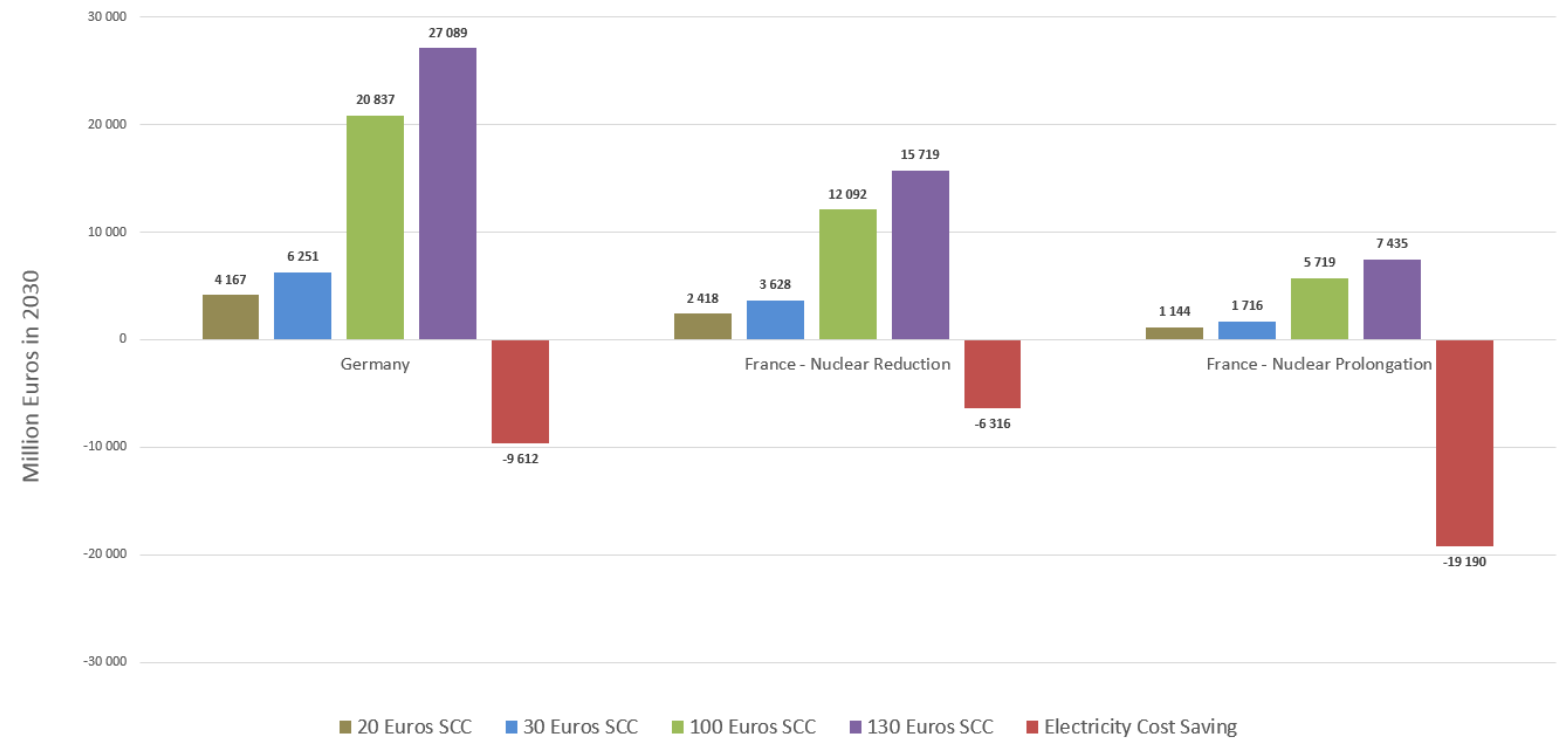

Figure 9: Overall electricity cost saving versus increased carbon cost (with 20, 30, 100 and 130 Euros SCC) when co-firing is included in the set of RES.

\footnotetext{
${ }^{16}$ We used a representative EUR/USD exchange rate of 2010 (from ECB) to convert the values.
} 
As illustrated in Figure 9, the cost saving from included co-firing in RES dominates the increased carbon cost when the SCC is low (20 and 30 Euros per $\mathrm{tCO}_{2}$ ), whereas the opposite occurs with higher SCC (100 and 130 Euros per $\mathrm{tCO}_{2}$ ). An exception comes from France when the out-of-lifetime nuclear stations are prolonged. In this case, the cost saving is very high and the increased $\mathrm{CO}_{2}$ emissions are slight (see discussions above), so that the cost saving always dominates the increased carbon cost, whatever the SCC.

\section{Conclusion}

This paper explores the effect of recognizing co-firing coal with biomass as renewable electricity so as to meet the RES mandatory obligations. We provide simulations for the French and German electricity mix, with investigations about consequences for cost savings in the power sector and $\mathrm{CO}_{2}$ emissions. We focus on France and Germany because they have substantial coal capacities and no support scheme for co-firing has been implemented in these countries so far. Hence, they constitute good cases of study for our analysis.

Results indicate that, if co-firing is recognized as a RES, coal would crowd-out traditional RES, not only with increased generation from existing coal plants, but also with additional investments in coal that would be substituted for wind, dedicated biomass, biogas, and other traditional RES. We find that the additional investments in coal may be more significant in France than in Germany, because the French coal capacities are smaller than the Germans, which limits the ability to use existing coal plants in order to meet the RES targets through co-firing. The additional coal capacities may attain a maximum of $18 \mathrm{GW}$ in France (when the model is implemented with exogenous decommissioning of old nuclear stations) against 14 GW in Germany. This corresponds to adding $27 \%$ of coal capacity in the German electricity by 2030 , whereas the same progression is more than $243 \%$ in France when old nuclear stations are decommissioned (107\% when nuclear is prolonged).

The analysis about $\mathrm{CO}_{2}$ emissions exhibits sharp increases when co-firing is recognized as a RES. Indeed, substituting coal to carbon-free RES, inevitably increases $\mathrm{CO}_{2}$ emissions, even if the emissions from coal are reduced through co-firing. The rise is more significant in Germany due to more coal capacities. In the case of France, the magnitude of increased emissions highly depends on the share of nuclear electricity, with fewer increase when old nuclear stations are prolonged. Finally, we find that including co-firing in the set of RES 
reduces the overall costs associated with managing the power system, because this allows complying with the RES constraint through a conventional and low-cost option that does not require additional investments in most cases. We also balanced the cost saving for the power sector with the increased social cost from higher $\mathrm{CO}_{2}$ emissions, in order to provide a more comprehensive evaluation of the actual benefit for the society. Results show that the cost saving is dominated by the increased carbon cost for the society if the carbon valuation is high (around 100 Euros per $\mathrm{tCO}_{2}$, which is not an usual value in studies evaluating the SCC), except in France when old nuclear stations are prolonged (in this case, the cost saving is very high and the increased $\mathrm{CO}_{2}$ emissions are slight, because coal compete higher in the merit order, and massive cheap and carbon-free nuclear remains in base-load generation).

Overall, our paper raises questions about the incentives to invest in traditional RES if cofiring is recognized as a RES. The consequences may be detrimental for the future energy mixes in European countries, with more coal (even if implemented under co-firing), less renewables, and resulting higher $\mathrm{CO}_{2}$ emissions. Beyond, this may be a concern for social acceptability, with populations that should be increasingly concerned by tackling climate change effects and reducing the share of polluting fossils in the energy mix. The cost generated by adaptations of electricity to climate policy is an important issues in this context. As illustrated in the recent US presidential campaign, policy makers can also face complicated trade-offs between climate, on the one hand, and employments from the coal industry, on the other hand. In all of this, co-firing can constitute an interesting solution. However, if it can provide efficient opportunities to reduce $\mathrm{CO}_{2}$ emissions in the short-run, it cannot be seen as a perennial strategy, which would jeopardize the necessary transition towards more renewable and less carbon in energy. This is something policy makers should remember when considering the opportunity of including provisions for co-firing in the support schemes for renewable electricity. 


\section{References}

Alexander, P., Moran, D., Rounsevell, M.D.A., and Smith, P., 2013. Modelling the perennial energy crop market: the role of spatial diffusion. Journal of the Royal Society Interface, 10 (20130656).

Argus, 2016. Argus biomass markets - Weekly biomass markets news and analysis. Issues 16-014.

AURES-Ecofys, 2016. Auctions for Renewable Energy Support in the Netherlands: Instruments and lessons learnt, Technical Report.

Bertrand, V., and Le Cadre, E., 2015. Simulating the use of biomass in electricity with the Green Electricty Simulate model: An application to the French power generation. CEC Working Paper, 2015-3.

Bubholz, M., and Nowakowski, R., 2010. Mapping of subsidy systems and future consumption of biomass, Svensk Fjärrvärme, Technical Report.

BMWi (German Federal Ministry for Economic Affairs and Energy), 2015. The Energy of the Future - Fourth Energy Transition Monitoring Report, Technical Report.

CGDD (Commissariat Général au Développement Durable), 2016. Les énergies renouvelables en France en 2015, French Ministry of Environment and Energy, Technical Report.

Delarue, E.D., Ellerman, A.D., D'haeseleer, W.D., 2010. Short-term $\mathrm{CO}_{2}$ abatement in the European power sector: 2005-2006. Climate Change Economics, 1 (2), 113-133.

Eurelectric, 2011. Power Statistics and Trends 2011, Technical Report.

Kannan, R., and Turton, H., 2013. A Long-Term Electricity Dispatch Model with the TIMES Framework. Evironmental Modeling and Assessment, 325-343.

Netherlands Enterprise Agency, 2016. SDE+ 2016 - Instructions on how to apply for a subsidy for the production of renewable energy, Technical Report.

Nordhaus, W. D., 2017. Revisiting the social cost of carbon. Proceedings of the National Academy of Sciences of the United States of America, 114 (7), 1518-1523.

Rentizelas, A.A., Tolis, A. I., and Tatsiopoulos, I.P., 2012. Investment planning in electricity production under $\mathrm{CO}_{2}$ price uncertainty. International Journal of Production Economics, 140, 622-629.

RTE, 2011. Statistiques Production Consommation Échanges 2011, Réseau de Transport d’Électricité (France).

Solier, B., 2014. An economic and ex post analysis of the impacts of the carbon price on the European power sector. $\mathrm{PhD}$ thesis, Paris-Dauphine University.

Weigt, H., Ellerman, A.D., Delarue, E., 2013. CO2 abatement from renewables in the German electricity sector: Does a CO2 price help? Energy Economics, 40, 149-158. 


\section{Appendix A}

Table 5: German nuclear phase-out plan, based on World Nuclear Association (www.world-nuclear.org) and WEPP data.

\begin{tabular}{llccc}
\hline City & Unit & $\begin{array}{c}\text { Year } \\
\text { Shutdown }\end{array}$ & $\begin{array}{c}\text { Year } \\
\text { Commissioning }\end{array}$ & MW \\
\hline \hline Biblis (68643) & BIBLIS A & 2011 & 1974 & 1225 \\
Biblis (68643) & BIBLIS B & 2011 & 1976 & 1300 \\
Brunsbuttel (25541) & BRUNSBUTTEL 1 & 2011 & 1977 & 806 \\
Essenbach (84051) & ISAR 1 & 2011 & 1979 & 912 \\
Geestacht (21502) & KRUMMEL 1 & 2011 & 1984 & 1402 \\
Neckarwestheim (74382) & NECKAR 1 & 2011 & 1976 & 840 \\
Philippsburg (76661) & PHILIPPSBURG 1 & 2011 & 1980 & 926 \\
Stadland (26935) & UNTERWESER 1 & 2011 & 1978 & 1410 \\
Grafenrheinfeld (97506) & GRAFENRHEINFELD 1 & 2015 & 1982 & 1345 \\
Gundremmingen (89355) & GUNDREMMINGEN B & 2017 & 1984 & 1344 \\
Philippsburg (76661) & PHILIPPSBURG 2 & 2019 & 1985 & 1458 \\
Brokdorf (25576) & BROKDORF 1 & 2021 & 1986 & 1480 \\
Emmerthal (31860) & GROHNDE 1 & 2021 & 1985 & 1430 \\
Gundremmingen (89355) & GUNDREMMINGEN C & 2021 & 1985 & 1344 \\
Lingen (49811) & EMS (LINGEN) 1 & 2022 & 1988 & 1400 \\
Essenbach (84051) & ISAR 2 & 2022 & 1988 & 1488 \\
Neckarwestheim (74382) & NECKAR 2 & 2022 & 1989 & 1400 \\
\hline
\end{tabular}

Table 6: Decommissioning of German nuclear units based on the nuclear phase-out plan (Table 5).

\begin{tabular}{ccc}
\hline Year & Per year decommissioning & Cumulated decommissioning \\
\hline \hline 2011 & 8821 & 8821 \\
2012 & 0 & 8821 \\
2013 & 0 & 8821 \\
2014 & 0 & 8821 \\
2015 & 1345 & 10166 \\
2016 & 0 & 10166 \\
2017 & 1344 & 11510 \\
2018 & 0 & 11510 \\
2019 & 1458 & 12968 \\
2020 & 0 & 12968 \\
2021 & 4254 & 17222 \\
2022 & 4288 & 21510 \\
\hline
\end{tabular}




\section{Appendix B}

Table 7: Main results for coal-based electricity with the 2020 and 2030 RES targets.

\section{Germany}

\begin{tabular}{lcccccc}
\hline & \multicolumn{2}{c}{2015} & \multicolumn{2}{c}{2020} & \multicolumn{2}{c}{2030} \\
\cline { 2 - 7 } & $\begin{array}{c}\text { Co-firing } \\
\text { in RES }\end{array}$ & $\begin{array}{c}\text { Co-firing } \\
\text { out RES }\end{array}$ & $\begin{array}{c}\text { Co-firing } \\
\text { in RES }\end{array}$ & $\begin{array}{c}\text { Co-firing } \\
\text { out RES }\end{array}$ & $\begin{array}{c}\text { Co-firing } \\
\text { in RES }\end{array}$ & $\begin{array}{c}\text { Co-firing } \\
\text { out RES }\end{array}$ \\
\hline \hline Yearly Power Generation (TWh elec $_{\text {per year) }}$ & 316 & 267.1 & 350.1 & 237.6 & 385 & 175.3 \\
Total Installed Capacities (GW) & 64.2 & 51.2 & 65.1 & 51.2 & 65.1 & 51.2 \\
Cumulated New Capacities (GW) & 13 & - & 13.9 & - & 13.9 & - \\
\hline
\end{tabular}

France - Nuclear Reduction

\begin{tabular}{|c|c|c|c|c|c|c|}
\hline & \multicolumn{2}{|c|}{2015} & \multicolumn{2}{|c|}{2020} & \multicolumn{2}{|c|}{2030} \\
\hline & $\begin{array}{l}\text { Co-firing } \\
\text { in RES }\end{array}$ & $\begin{array}{l}\text { Co-firing } \\
\text { out RES }\end{array}$ & $\begin{array}{l}\text { Co-firing } \\
\text { in RES }\end{array}$ & $\begin{array}{l}\text { Co-firing } \\
\text { out RES }\end{array}$ & $\begin{array}{l}\text { Co-firing } \\
\text { in RES }\end{array}$ & $\begin{array}{l}\text { Co-firing } \\
\text { out RES }\end{array}$ \\
\hline Yearly Power Generation ( $\mathrm{TWh}_{\text {elec }}$ per year) & 83.6 & 39 & 99.8 & 22.1 & 193.4 & 58.3 \\
\hline Total Installed Capacities (GW) & 24.5 & 12.8 & 25.7 & 12.8 & 25.7 & 12.8 \\
\hline Cumulated New Capacities (GW) & 17 & 5.3 & 18.2 & 5.3 & 18.2 & 5.3 \\
\hline \multicolumn{7}{|c|}{ France - Nuclear Prolongation } \\
\hline & \multicolumn{2}{|c|}{2015} & \multicolumn{2}{|c|}{2020} & \multicolumn{2}{|c|}{2030} \\
\hline & $\begin{array}{l}\text { Co-firing } \\
\text { in RES }\end{array}$ & $\begin{array}{c}\text { Co-firing } \\
\text { out RES }\end{array}$ & $\begin{array}{l}\text { Co-firing } \\
\text { in RES }\end{array}$ & $\begin{array}{c}\text { Co-firing } \\
\text { out RES }\end{array}$ & $\begin{array}{l}\text { Co-firing } \\
\text { in RES }\end{array}$ & $\begin{array}{l}\text { Co-firing } \\
\text { out RES }\end{array}$ \\
\hline Yearly Power Generation $\left(\mathrm{TWh}_{\text {elec }}\right.$ per year) & 55.8 & 18.5 & 65.3 & 14.6 & 78.5 & 10.5 \\
\hline Total Installed Capacities (GW) & 15.5 & 7.5 & 15.5 & 7.5 & 15.5 & 7.5 \\
\hline Cumulated New Capacities (GW) & 8 & - & 8 & - & 8 & - \\
\hline
\end{tabular}




\section{Appendix C}

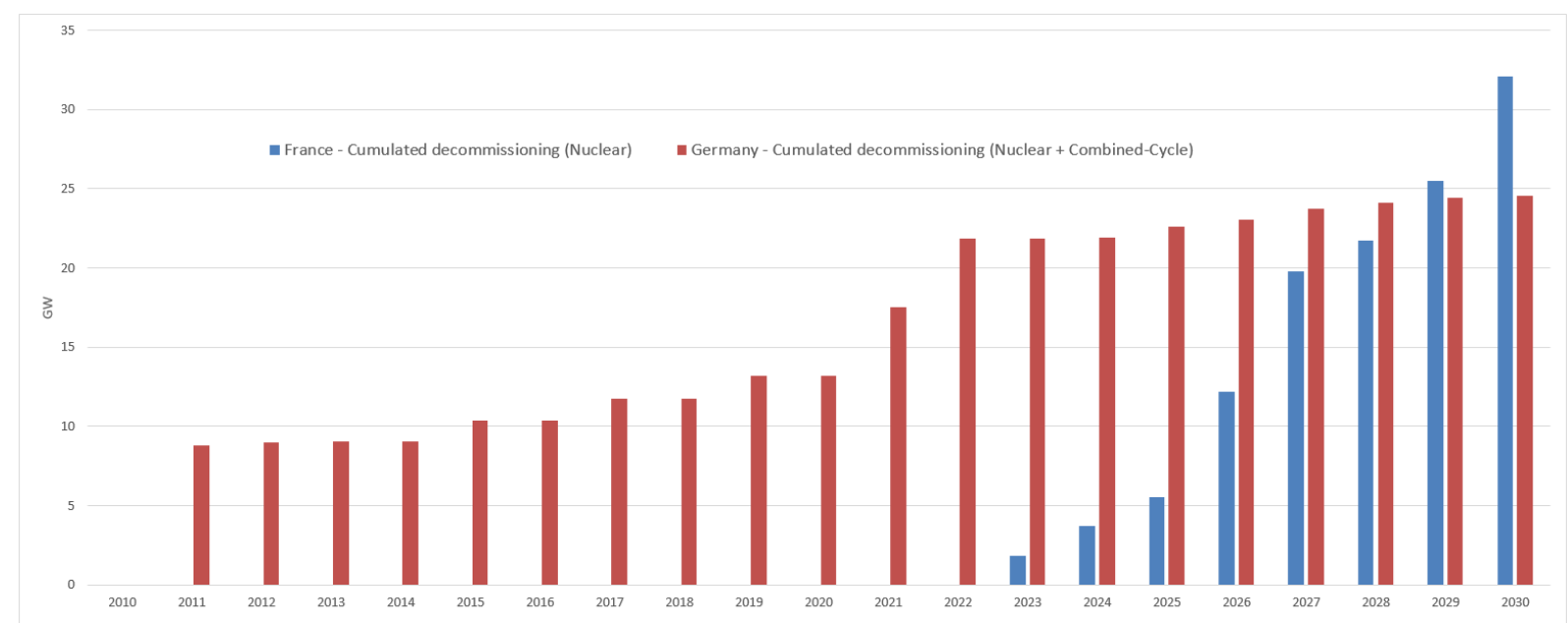

Figure 10: Comparative evolution of French and German decommissioning for main conventional technologies.

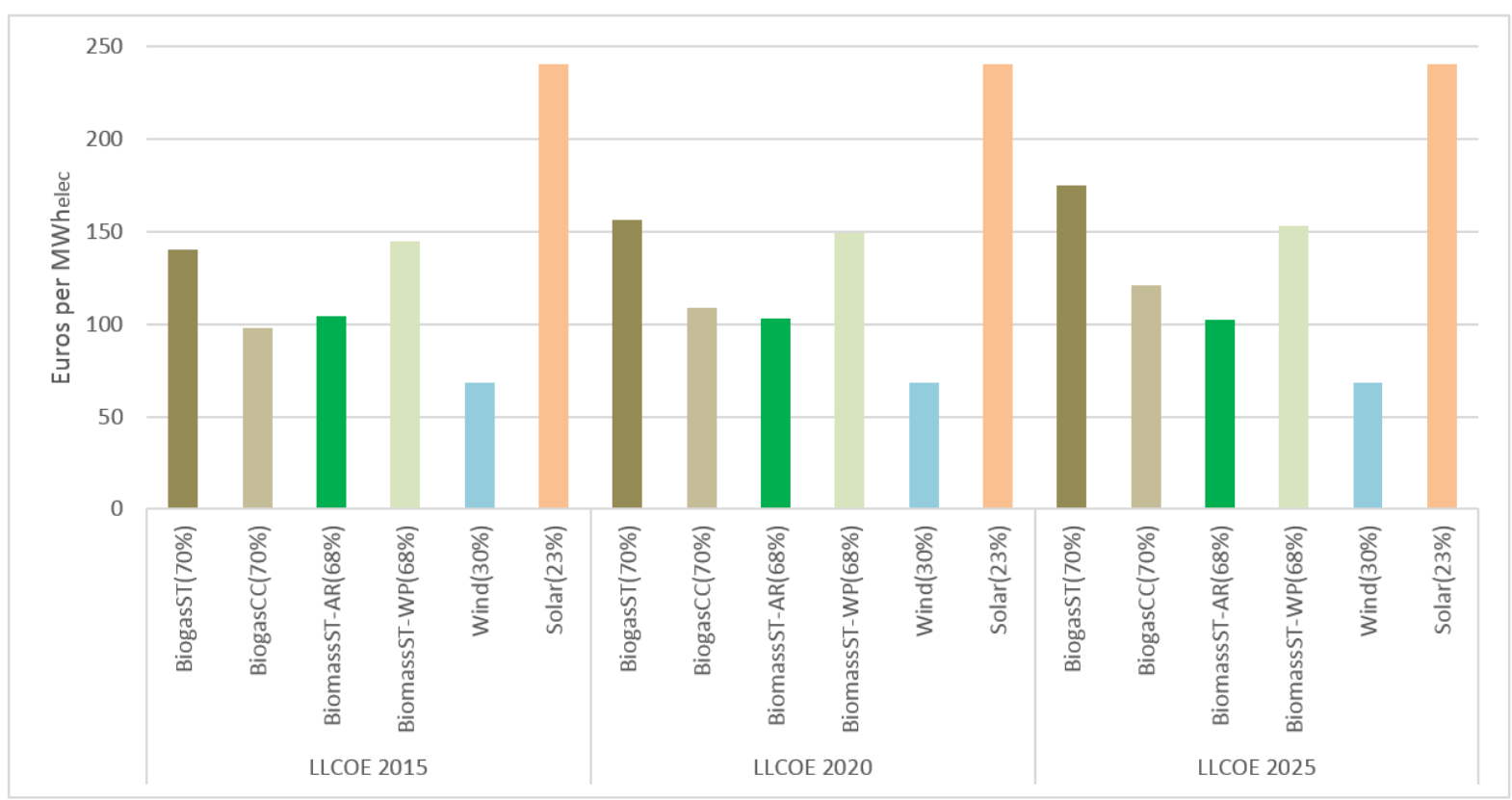

Figure 11: Levelized lifetime cost of electricity (LLCOE) computed for different RES technologies (Biogas-ST $=$ Biogas Steam Turbine $;$ Biogas $-\mathrm{CC}=$ Biogas Combined Cycle $;$ Biomass-ST $=$ Dedicated biomass Steam Turbine). For each technology, the value in bracket reflects the availability factor. In the case of biomass, AR stands for Agricultural Residues and WP for Wood Pellets. 


\section{WORKING PAPER}

$n^{\circ} 2017-04 \cdot$ May 2017

\section{LATTER ISSUES}

Co-firing coal with biomass under mandatory obligation for renewable electricity: Implication for the electricity mix Vincent BERTRAND

Intertemporal abatement decisions under ambiguity aversion in a Cap and Trade Simon QUEMIN

Households energy consumption and transition toward cleaner energy sources Olivier DAMETTE, Philippe DELACOTE, Gaye DEL LO

Transitional restricted linkage between Emissions Trading Schemes Simon QUEMIN, Christian DE PERTHUIS

A new behavioral framework to analyze preference construction and decision processes within the modal choice Hugo BOIS

Demand pull instruments and the development of wind power in Europe: a counter-factual analysis Marc BAUDRY, Clément BONNET

Risk as a limit or an opportunity to mitigate GHG emissions? Benjamin DEQUIEDT, Emmanuel SERVONNA

The economic analysis of the forest transition: a review Edward B. BARBIER, Philippe DELACOTE, Julien WOLFERSBERGER n'2017-04

$n^{\circ} 2017-03$

$n^{\circ} 2017-02$

$n^{\circ} 2017-01$

$n^{\circ} 2016-08$

$n^{\circ}$ 2016-07

$n^{\circ} 2016-06$

n'2016-05
Climate

ECONOMICS

ChaIR
DAUPHINE 